\title{
Deciphering the Secrets of UFO Field-Propulsion Technology
}

\author{
Deep Bhattacharjee ${ }^{1}$ \\ ${ }^{1}$ Electro-Gravitation Simulation and Propulsion Laboratory, AATWRI Aerospace and \\ Defense
}

November 30, 2020

\begin{abstract}
Detailed analysis of the UFO structure along with Field Propulsion has been provided in this paper subject to Anti-Gravity, Electrohydrodynamics and warp drive with superluminal speeds violating General, Special Relativity and Newton's laws of motion.
\end{abstract}

\section{Hosted file}

UFOLOGY-Deep.pdf available at https://authorea.com/users/379677/articles/496003-decipheringthe-secrets-of-ufo-field-propulsion-technology 